
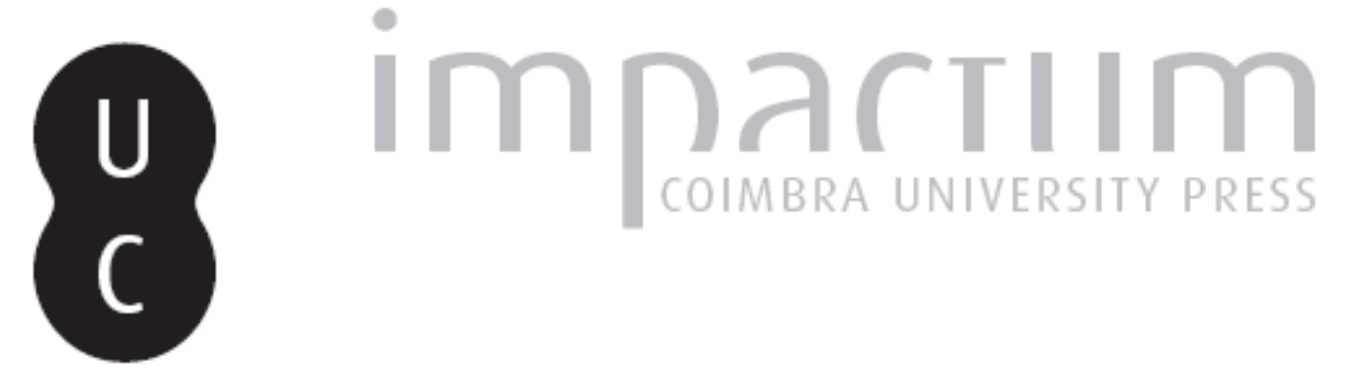

\title{
Latin historiography and Plutarch: the case of Ammianus Marcelinus
}

Autor(es): Hengst, Daan den

Publicado por: International Plutarch Society

URL persistente:

URI:http://hdl.handle.net/10316.2/37590

DOI:

DOI:http://dx.doi.org/10.14195/0258-655X_2_3

Accessed : $\quad$ 26-Apr-2023 12:49:34

A navegação consulta e descarregamento dos títulos inseridos nas Bibliotecas Digitais UC Digitalis, UC Pombalina e UC Impactum, pressupõem a aceitação plena e sem reservas dos Termos e Condições de Uso destas Bibliotecas Digitais, disponíveis em https://digitalis.uc.pt/pt-pt/termos.

Conforme exposto nos referidos Termos e Condições de Uso, o descarregamento de títulos de acesso restrito requer uma licença válida de autorização devendo o utilizador aceder ao(s) documento(s) a partir de um endereço de IP da instituição detentora da supramencionada licença.

Ao utilizador é apenas permitido o descarregamento para uso pessoal, pelo que o emprego do(s) título(s) descarregado(s) para outro fim, designadamente comercial, carece de autorização do respetivo autor ou editor da obra.

Na medida em que todas as obras da UC Digitalis se encontram protegidas pelo Código do Direito de Autor e Direitos Conexos e demais legislação aplicável, toda a cópia, parcial ou total, deste documento, nos casos em que é legalmente admitida, deverá conter ou fazer-se acompanhar por este aviso.

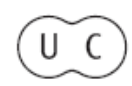




\section{Ploutarchos, n.s.}

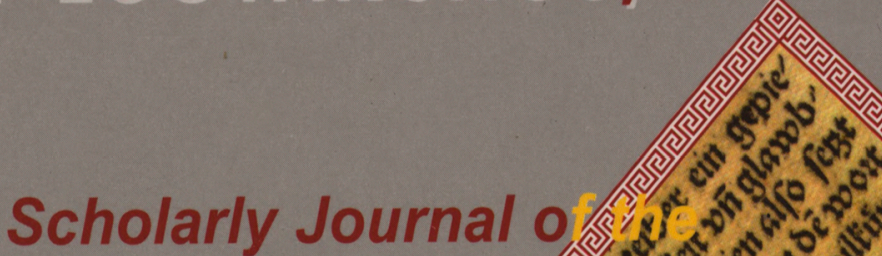

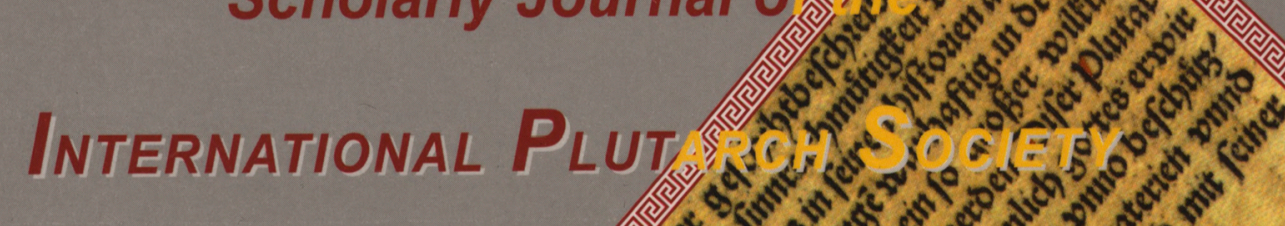

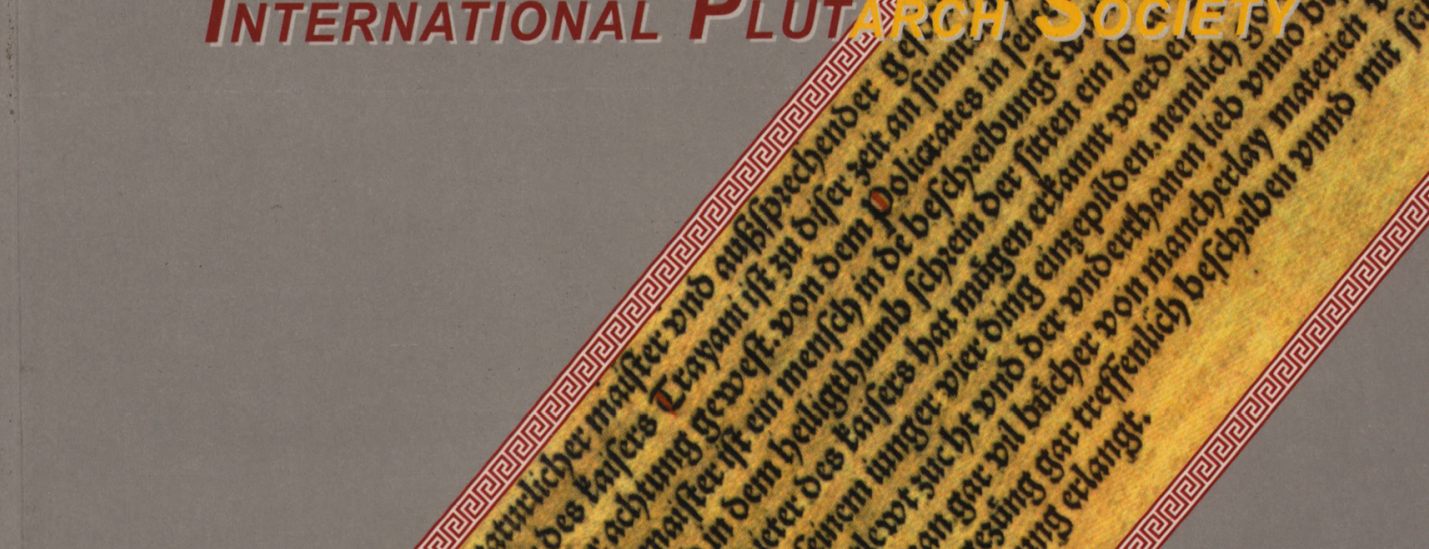




\title{
Latin Historiography and Plutarch: The Case of Ammianus Marcellinus \\ by \\ Daan den Hengst \\ University of Amsterdam
}

\begin{abstract}
Plutarch's influence on the historical thought of subsequent ages is a vast and fascinating subject. One major historical work from Late Antiquity has not yet received any systematic attention in connection with Plutarch, the Latin Res Gestae of Ammianus Marcellinus. Since both authors are Greek by education and birth, Platonists, and deeply involved in Roman history, it is reasonable to suspect that Ammianus might have consulted Plutarch. This paper will look for possible traces of Plutarch's works in Ammianus.
\end{abstract}

Plutarch's influence on the historical thought of subsequent ages is a vast and fascinating subject. One major historical work from Late Antiquity has, to the best of my knowledge, not yet received any systematic attention in connection with Plutarch. I refer to the Latin Res Gestae of Ammianus Marcellinus, dating from the last decade of the fourth century. Ammianus deals with recent history, in which the central figure is the highly controversial emperor Julian the Apostate. It is important to keep in mind that Ammianus knew Julian personally and that he accompanied him on his Persian campaign, in the course of which the emperor died on the battlefield. Despite his severe criticism of some key aspects of Julian's policies, Ammianus shows a profound admiration for Julian, who is, quite literally, his hero.
The emperor, his historian and the 'evening sun of paganism', as my compatriot Hartman used to call Plutarch, have much in common. By birth and education they were Greek and proud of it. By choice and vocation they were deeply involved in Roman history, Plutarch and Ammianus writing it, the emperor making it himself. More importantly, all three of them considered themselves Platonists. This is well known from the writings of Plutarch and Julian, but Ammianus, too, on the basis of his numerous digressions, has been aptly characterised by Szidat as a representative of what he calls Vulgärneuplatonismus. All in all, there is ample reason to look for possible traces of Plutarch's works in Ammianus.

I begin with a technical passage. In his digression on siege engines in $R G$ 23.4 Ammianus mentions the mobile siege tower or helepolis: "a machine 
well known to the historians, which we Greeks call helepolis." Two Greek historians known to us describe Demetrius' tower, Diodorus Siculus and Plutarch, in his Life of Demetrius 20-1. The technical description in Ammianus shows a strong resemblance to that in Plutarch and Ammianus makes in passing two additional remarks that, in my opinion, betray his indebtedness to Plutarch. Ammianus writes in $R G$ 23.04,10: Cuius opera diuturna Demetrius, Antigoni filius regis, Rhodo aliisque urbibus oppugnatis Poliorcetes est appellatus ("by using this machine for a long time Demetrius, the son of King Antigonus, captured Rhodes and other cities and gained the name of Poliorcetes"). The unnecessary and, for Ammianus, unusual mention of Demetrius' father can be explained by the fact that Plutarch had devoted the chapters preceding his description to Antigonus. Secondly, the words opera diuturna in my opinion

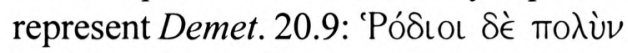

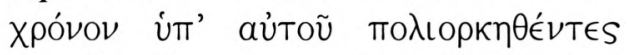
"the Rhodians having been besieged by him for a long time."

In two other of the numerous digressions that Ammianus inserts into his Res Gestae, he makes use of themes that he probably had found in Plutarch. In $R G$ 14. 6,1, the famous digression on Roman life and manners, Ammianus mentions the harmony of Virtus and Fortuna as the basis of Rome's greatness: Roma ut augeretur sublimibus incrementis, foedere pacis aeternae
Virtus convenit atque Fortuna plerumque dissidentes ("Valour and good fortune, which are so often at variance, conspired in an unbreakable bond, to assist the steps by which Rome rose to glory"). This is a theme from the topical discussion, found in Plutarch's essay De Fortuna Romanorum, on the relative merit of the Greeks and the Romans, where it is asked whether Rome owed its success to fortune or to its own excellence and bravery. It is of course hazardous to postulate an intertextual relation where such a well-worn topos is concerned, but in this case there are again textual resemblances that make it plausible that Ammianus had Plutarch's text in mind when he wrote this passage. Note the casual plerumque dissidentes, which is completely irrelevant in Ammianus' line of thought, but very prominent in Plutarch's De Fortuna Romanorum, which opens with the words:

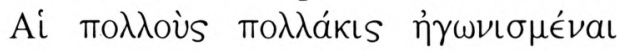

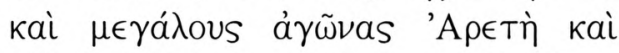
Túxn ("Virtue and Fortune who have often fought many large battles"), after which Plutarch goes on to say in $316 \mathrm{E}$ that the two forces made their peace and worked harmoniously together to establish Rome' greatness. This is echoed in Ammianus' words foedere pacis aeternae Virtus convenit atque Fortuna. In his digression Ammianus shows great respect for Rome as lawgiver and bringer of peace. Elsewhere $(16.10,13)$, he even calls the city imperii virtutumque omnium lar ("the home of empire and of all the virtues"), which is 
in complete accordance with Plutarch's positive assessment of Rome's role in the world. So in this very personal (and anachronistic!) evaluation of the capital city and its place in history, Ammianus turns to Plutarch to find an explanation for its rise to power and its greatness.

The third theme to which I would like to draw attention is the digression on the role of the genius in $R G 21.14,3-5$. In the preceding sections Ammianus has told his readers that on the eve of his death the emperor Constantius admitted to his closest confidants that he felt abandoned because he could no longer see a mysterious something (secretum aliquid) which he thought dimly appeared to him from time to time. This he believed to be a guardian spirit appointed to protect him, and its departure to be a sign that he was about to leave this world. The follows the digression proper. First, Ammianus tells us that "the genius is visible to few people, in fact only to those of unusual merit": admodum tamen paucissimis visa, quos multiplices auxere virtutes. He goes on to quote Menander, in Greek, who said that every man receives at birth a guardian spirit who guides him on the path of life, a quotation found also in Plutarch De tranquillitate animi $474 \mathrm{~B}$ :

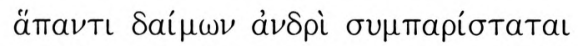

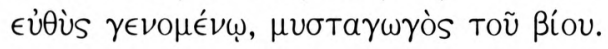

In section 5, Ammianus enumerates great figures from history whom their guardian spirits had attended: quorum adminiculis freti praecipuis Pythagoras enituisse dicitur et Socrates Numaque
Pompilius et superior Scipio et, ut quidam existimant, Marius et Octavianus, cui Augusti vocabulum delatum est primo, Hermesque Termaximus et Tyaneus Apollonius atque Plotinus ("It was by their particular support that Pythagoras and Socrates and Numa Pompilius became famous, not to mention the elder Scipio and, as some believe, Marius, and Octavian, who was the first to bear the title of Augustus. There are also Hermes Trismegistus and Apollonius of Tyana and Plotinus"). This catalogue of 'Wundermänner', $\theta \in$ ĩol $a ̋ \nu \delta \rho \in S$, is carefully chosen by Ammianus from Greek and Roman history in the manner of Plutarch's Parallel Lives.

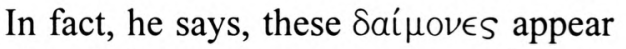
already in Homer, who presents them as gods, whereas in reality they were guardian spirits, who aided their protégés in battle and elsewhere. On the Greek side Ammianus mentions Pythagoras, Socrates, Hermes Trismegistos (or Termaximus in the Latin form), Apollonius of Tyana and Plotinus. From Roman history we find the priest-king Numa Pompilius, Scipio Maior, and, with some reservation (ut quidam existimant) Marius and Octavianus, later called Augustus. The Roman list is clearly inferior to the Greek, but it is evident that Ammianus has made an effort to be even-handed. Rounding off the digression, he insists once again on the prerequisite of purity. The genii impart their wisdom only to those who are pure in spirit and kept from the pollution of $\sin$ (a colluvione 
peccandi discretas) through immaculate association with the body (immaculata corporis societate), which is, by the way, the only place in pagan literature where immaculatus is used in its metaphorical meaning.

It is my contention that in this ideologically charged digression Ammianus has made use of information he found in Plutarch. As Apuleius and Tertullian had done before him, Ammianus uses the term genius as the Latin equivalent of the Greek $\delta a i ́ \omega \nu$ (witness his quotation from Menander). This opens the way for Greek philosophical ideas on demonology, found with great frequency and prominence in Plutarch, to be connected to the archetypical Roman notion of the genius. Firstly, the notion that only persons of high moral standing are allowed actually to see their demon, is expressed in Plutarch's Numa

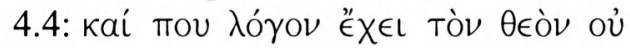

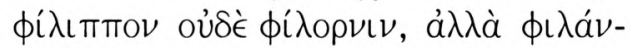

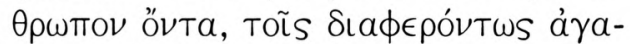

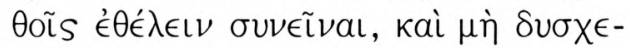

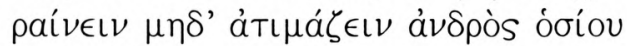

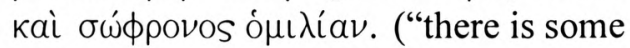
reason in supposing that Deity, who is not a lover of horses or birds, but of men, should be willing to consort with men of superlative goodness and should not dislike or disdain the company of a wise and holy man"). The theme recurs in Plutarch's discussion of Socrates' Saıнóvıov in de genio Socratis 588D-E,

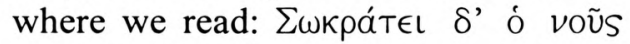

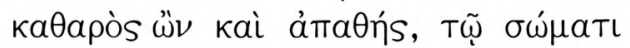

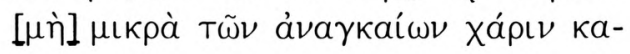

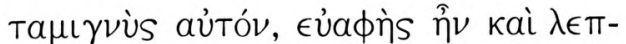

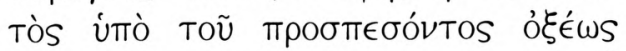

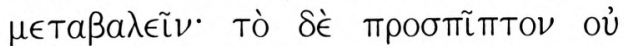

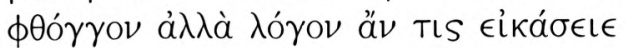

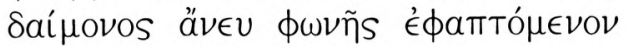

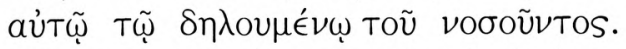
"Socrates, on the other hand, had an understanding which, being pure and free from passion, and commingling with the body but little, for necessary ends, was so sensitive and delicate as to respond at once to what reached him. What reached him, one would conjecture, was not spoken language, but the unuttered words of a daemon, making voiceless contact with his intelligence by their sense alone."

With regard to the Greek exempla listed by Ammianus, there is an ample choice of sources, apart from Plutarch, to which he may have turned. For Pythagoras I think of Iamblichus' biography and of Eunapius' Vitae sophistarum, to stay within the circle of authors dear to Julian and his intellectual circle. The same Eunapius, in his Life of Apollonius, calls the sage of Tyana "something between god and man." About Plotinus we read in chapter 10 of his biography by Porphyry that when his guardian spirit was evoked in the temple of Isis at Rome, there appeared a

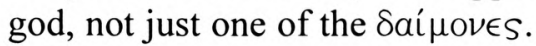

For the Roman exempla however, there are, as far as I have been able to find, no sources except Plutarch. The data concerning Socrates' Roman counterpart, Numa Pompilius, are taken from Plutarch's biography (4.2), in which the nymph Egeria is explicitly 


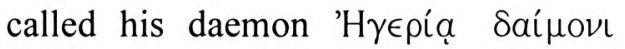

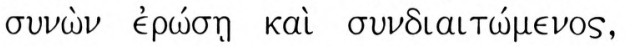

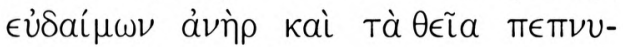

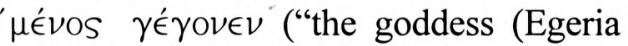
loved him and it was his communion with her that gave him a life of blessedness in the love of the gods and a wisdom more than human"). Note that this statement is followed immediately by the passage from the Numa quoted above, which makes it even more likely that Ammianus had this passage in mind when he composed this digression.

About Marius' contacts with a daemon Ammianus, as we saw, is somewhat sceptical. The only candidate for the role of daemon seems to be the Syrian priestess Martha, mentioned in Plutarch's bio-

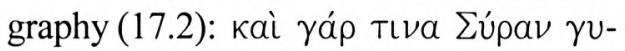

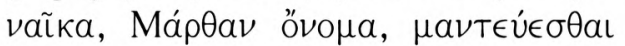

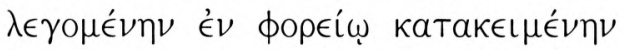

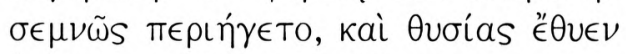

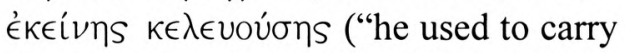
about ceremoniously in a litter a Syrian woman, named Martha, who was said to have the gift of prophecy, and he would make sacrifices at her bidding").

Since Plutarch's Life of Augustus has not been transmitted, it is impossible to say whether Ammianus found this piece of information in Plutarch too, but I suspect that the apparition of the muleteer Eutychus and his mule Nicon with their telling names, mentioned both in Suetonius vita Augusti 96 and in Plutarch's Life of Antony 65.5 Kaioapl

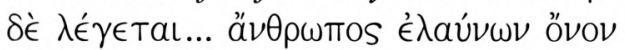

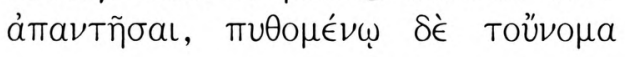

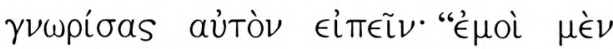

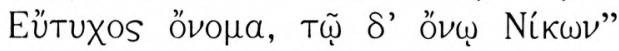
("Caesar, we are told, ...was met by a man driving an ass. Caesar asked the man his name, and he, recognizing Caesar, replied: 'my name is Prosper, and my ass's name is Victor"'). was interpreted in this way by Plutarch and taken over by Ammianus.

If I am right in thinking that Ammianus used Plutarch as a source, he did so not just for minor historical details, as in the digression on siege engines, but in programmatic statements about the position of Rome in the world and in digressions of a lay philosophical nature such as the one on the genius. The special ideological importance of this digression and its topicality will become clear if we realize that in the last decades of the fourth century, when Ammianus wrote his Res Gestae, the genius was a highly controversial subject. Other pagan contemporary authors, such as Servius and Symmachus, emphatically mention the genius in their works. In view of the fact that the cult of the genius, in whatever form, was expressly forbidden by Theodosius in a law from 392 (Codex Theodosianus $16.10,12$ ) shows that the views a person held on this subject were a touchstone of his religious affiliation. That helps to explain why the Christian poet Prudentius, ten years later, devoted more than a hundred lines of his contra Symmachum to combat the belief in the Roman genius, culminating in the crushing statement (2.386) genio qui nusquam est nec 
fuit umquam ("the genius, which does that the intellectual circle around the not exist nor ever has existed"). emperor Julian, including writers like Ammianus' digression on the genius is Eunapius and Himerius, read and one of the instances in his work in which admired Plutarch. Ammianus, who he polemicizes against Christianity with- breathes the same spirit of pagan out explicitly mentioning it.

It was my intention in this paper to add a footnote to Plutarch's Rezeptionsgeschichte. Hirzel had shown already Neoplatonism, used Plutarch both incidentally and in digressions that are central to this last great work that belongs to the Roman tradition of historiography. 